Ann. Biol. anim. Bioch. Biophys., 1977, 17 (6), 1101-1105.

\title{
An improved radioenzymatic and dansylation method for the determination of m-octopamine, p-octopamine and phenyl- -ethanolamine in biological samples
}

par J.-C. DAVID

Laboratoire de Biochimie du Développement, Institut de Biologie moléculaire du CNRS

et de I'Université de Paris VII

2, place Jussieu 75221 Paris Cedex 05 France.

Summary. We have described a simple method for the simultaneous determination of two octopamine isomeres, $m$ and $p$, as well as for phenylethanolamine in biological tissues. The use of radioactive dansyl chloride and radioactive $S$ adenosyl methionine led to a tenfold increase in sensitivity.

Although octopamine has been identified in the brain and in several peripheral adrenergic innervated tissues of mammals with (Kakimoto and Armstrong, 1962) or without (Molinoff and Axelrod, 1969) a monoaminoxidase inhibitor pretreatment, only one method is currently available for its determination in biological materials (Molinoff and Axelrod, 1969). This method, however, does not discriminate between the meta and para isomers of octopamine and its specificity has been questioned (Harmar and Horn, 1976). Recently, a more specific and sensitive method has been described (Danielson, Boulton and Robertson, 1977) in which simultaneous determination of p-octopamine, m-octopamine and phenylethanolamine is also based on the $\mathrm{N}$-methylation of $\beta$-hydroxylated phenylethylamines by the enzyme phenylethanolamine $\mathrm{N}$-methyl transferase (PNMT : EC 2.1.28) using $\left[{ }^{3} \mathrm{H}\right]$ methyl-S-adenosyl-1methionine $\left[{ }^{3} \mathrm{H}\right]$ SAM) as donor, as previously described by Molinoff and Axelrod (1969). The specificity of this method can be considerably improved by further dansylation of the $\mathrm{N}$-methylated amines and their subsequent separation by this layer chromatography. As little as 10 pg m-octopamine, p-octopamine and phenylethanolamine can be measured.

We have tried to develop a more sensitive method because the levels of the three amines in most mammalian tissues are very low, being in the range of $1 \mathrm{ng} / \mathrm{g}$ even after aminoxydase inhibitor pretreatment (Danielson, Boulton and Robertson, 1977). One way to increase the sensitivity is to augment the specific radioactivity of the SAM moiety ; the other is to use radioactive dansylchloride. SAM with more specific radioactivity is not presently available, and so we decided to use radioactive dansylchloride. 


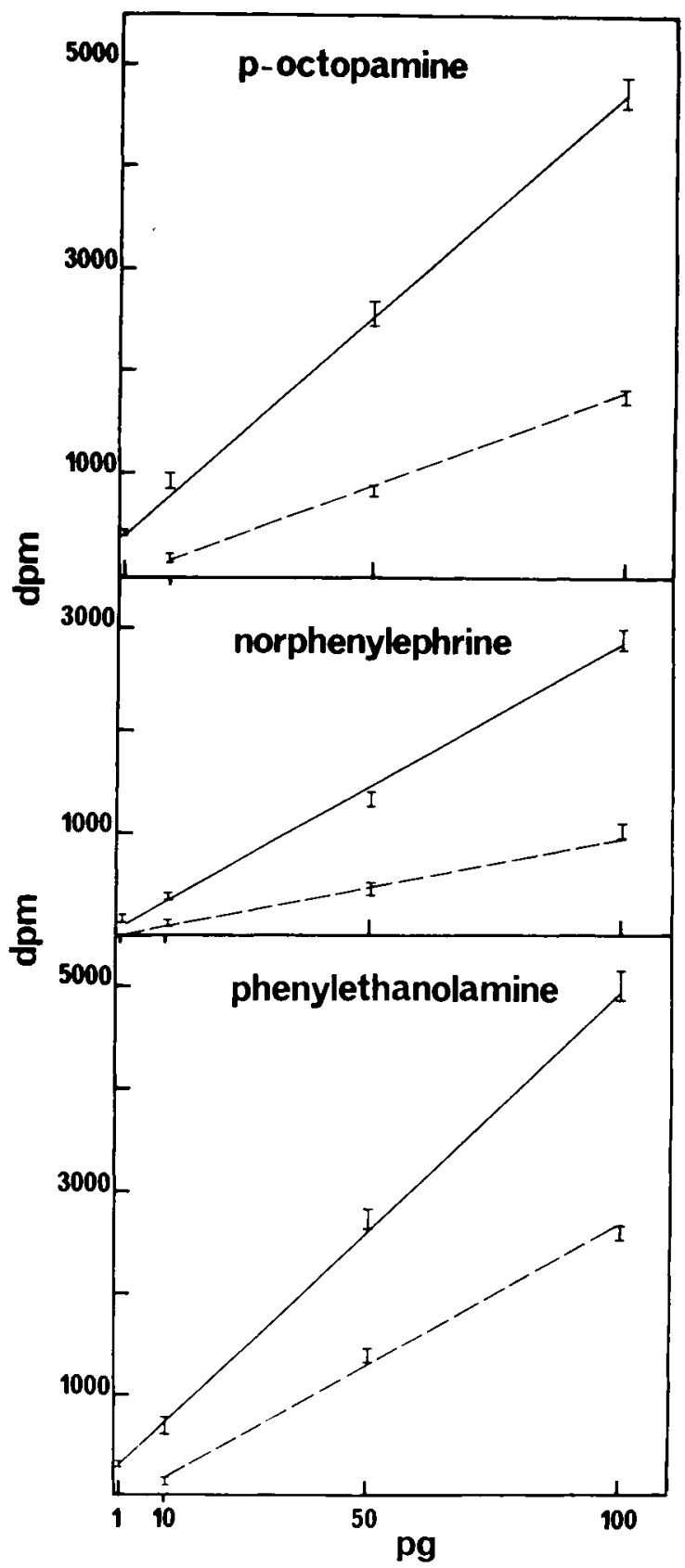

FIG. 1. - Concentrations of $10,50,100 \mathrm{pg}$ of p-octopamine (A), m-octopamine (B), penylethanolamine (C) were allowed to react with ${ }^{3} \mathrm{H}$ SAM and non-radioactive dansylchloride and the radioactivity associated to the dansylated amines measured (dashed lines). Concentrations of 1,10 , $50,100 \mathrm{pg}$ p-octopamine (A), m-octopamine (B) and phenylethanolamine (C) were allowed to react with both radioactive SAM and dansylchloride. The radioactivity associated to the dansylated amines was measured (solid lines). The results are the mean of four experiments. 


\section{Material and methods.}

DL-p-octopamine, DL-phenylethanolamine, DL-noradrenaline and dansylchloride were obtained from Sigma Chemical Co., Lid. The sources of the other drugs were as follows: DL-N-methyloctopamine tartrate (DL-p-synephrine tartrate), Koch Light and Co., Ltd. ; N-methyl-phenylethanolamine-HCl, Aldrich Chemical. Pargyline was a gift of the Abbott Laboratories and DL-norphenylephrine $\mathrm{HCl}$ ( $m$-octopamine $\mathrm{HCl}$ ) was donated by Pharmacia AB, Uppsala, Sweden.

$\left[{ }^{3} \mathrm{H}\right] \mathrm{S}$-adenosyl methionine (12.25 $\left.\mathrm{Ci} / \mathrm{nmole}\right)$ and dansylchloride (1-dimethylaminonaphtalene 5 sulfonyl chloride) $(12.5 \mathrm{Ci} / \mathrm{nmole})$ were supplied by $\mathrm{New}$ England Nuclear. PNMT was prepared according to the method of Saelens ef al. (1967) using bovine adrenal glands.

In order to test the method with biological samples, six determinations of $m$-octopamine, p-octopamine and phenylethanolamine content were performed on the salivary glands of normal rat (Zivic-Miller, Pittsburg, USA). After they were killed, the salivary glands were immediately removed, frozen on dry ice and weighed.

The quantification of the three amine was basically as described by Danielson ef al. (1977) with the following modifications : tissues were homogenized in 10 volumes of ice-cold $1 \mathrm{M}$ Tris- $\mathrm{HCl}$ buffer, $\mathrm{pH} \mathrm{8.6,} \mathrm{containing} 1 \mathrm{mM}$ pargyline. Homogenates were then heated to $100{ }^{\circ} \mathrm{C} 3 \mathrm{~min}$ in a boiling water bath. After centrifugation at $10.000 \mathrm{~g}$ for $5 \mathrm{~min}, 150 \mu \mathrm{l}$ aliquots of supernatant were incubed with $60 \mu \mathrm{l} 0.05 \mathrm{M}$ Tris- $\mathrm{HCl}$ buffer, $\mathrm{pH}$ 8.6, solution containing $40 \mu \mathrm{l}$ partially purified PNMT and $0.05 \mathrm{nmole}\left[{ }^{3} \mathrm{H}\right] \mathrm{SAM}$. The reaction was stopped after $45 \mathrm{~min}$ by addition of $200 \mu \mathrm{l}$ $0.5 \mathrm{M}$ borate buffer, $\mathrm{pH} 11.0$, saturated with sodium chloride and containing $2 \mu \mathrm{g}$ each of p-synepthrine, phenylephrine and $\mathrm{N}$-methyl phenylethanolamine. Following extraction with ethylacetate and complete evaporation, the residues were dissolved in $1 \mathrm{ml}$ saturated sodium carbonate and $0.5 \mathrm{ml}$ acetate containing non-radioactive dansylchloride $(8 \mathrm{mg} / \mathrm{ml})$ and $0.5 \mathrm{nmole}\left[{ }^{3} \mathrm{H}\right]$ dansylchloride and allowed to react overnight in the dark. The dansylated amines were separated according to Danielson et al. (1977). The spots were then scraped and the radioactivity counted. Blanks and standards were prepared using aliquots of $0.1 \mathrm{M}$ Tris- $\mathrm{HCl}(\mathrm{pH} \mathrm{8.6)}$ solutions and buffer solutions containing known amounts of p-octopamine, norphenylephrine and phenoylethanolamine throughout the entire procedure.

\section{Results and discussion.}

We report a procedure involving both $\left[{ }^{3} \mathrm{H}\right]$ SAM and $\left[{ }^{3} \mathrm{H}\right]$ dansylchloride which marks a significant increase in sensitivity for the three amines.

After separation on the third thin-layer chromatogram, fractionation was complete with no evidence of cross contamination by the other PNMT substrates. Figure 1 depicts a linear relationship between the amount of p-octopamine, norphenylephrine and phenylethanolamine added and the radioactivity present on the spots of the third chromatogram. This proportionality is shown with the assay involving only SAM as labeled material and the sensitivity of the assay (defined as the amount of amine required to produce twice the count rate of the blank) was $10 \mathrm{pg}$. When both SAM 
J. C. DAVID

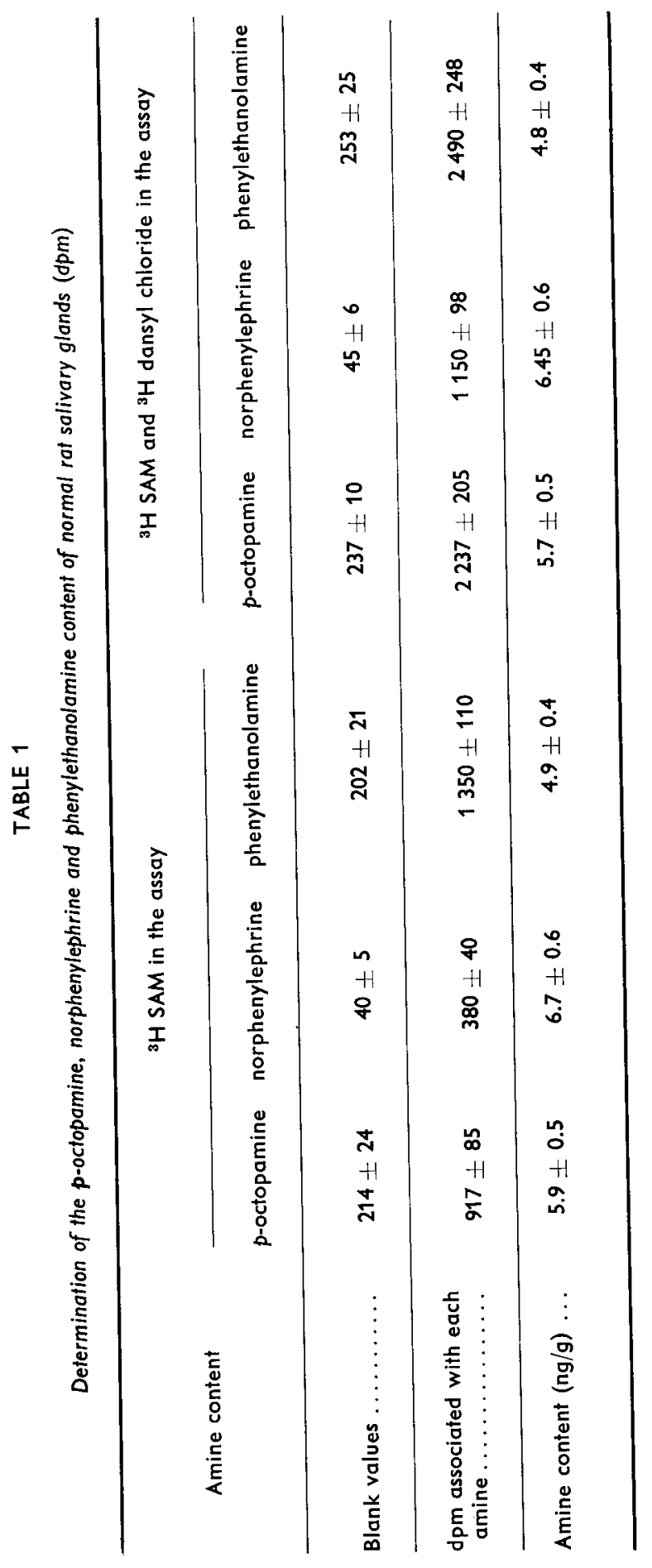


and dansylchloride were used as labeled material, a linear relationship was still found with a sensitivity as low as $1 \mathrm{pg}$. When both radioactives SAM and dansylchloride were used, the amount of radioactivity found associated with the chosen amounts of each amine was 3 times greater with p-octopamine and norphenylephrine and 2 times greater with phenylethanolamine than it was when SAM was the only radioactive material present in the reaction.

This improved method was used for the determination of the content of the three amines in biological samples. The blank, dpm and amounts of the three different amines in the salivary glands of the normal rat are shown in table 1 . The values are in good agreement for the two different methods and all three amines are present in similar concentrations. The above-described method is an accurate and reproducible one for determining p-octopamine and norphenylephrine content in biological material. The use of radioactive SAM and radioactive dansylchloride in this asseay led to a ten-fold increase of sensitivity as compared to the method originally described by Danielson ef al. (1977) and a 100-fold increase as compared to that of Harmar and Horn (1976).

Reçu en juin 1977.

Accepté en septembre 1977.

Acknowledgements. - Part of this work has been completed under an exchange program. The author is grateful to the Canadian and French governments for support as well as to Dr. Boulton for laboratory facilities.

Résumé. Nous décrivons une méthode simple pour la détermination simultanée des deux isomères $m$ et $p$ de l'octopamine ainsi que la phénylethanolamine dans les tissus biologiques. L'utilisation de chlorure de dansyl radioactif et de $S$ adenosyl methionine radioactive conduił à une augmentation de la sensibilité de près de 10 fois.

\section{References}

DANIELSON T. J., BOULTON A. A., ROBERTSON H. A., 1977 . m-Octopamine, p-Octopamine and phenylethanolamine in mammalian brain : a sensitive, specific assay and effects of drugs. J. Neurochem (in press).

HARMAR A. J., HORN A. S., 1976. Octopamine in mammalian brain : rapid post mortem increase and effects of drugs. J. Neurochem., 26, 987-993.

KAKIMOTO Y., ARMSTRONG M. D., 1962. On the identification of octopamine in mammals. J. biol. Chem., 237, 422-427.

MOLINOFF B. P., AXELROD J., 1969. Octopamine normal occurence in sympathetic nerves. Science, 164, 428-429.

SAELENS J. K., SCHOEN M. S., KOVACS G. B., 1967. An enzyme assay for norepinephrine in brain tissue. Biochem. Phormocol., 16, 1043-1049. 